\begin{tabular}{cc}
$\begin{array}{c}\text { ÇÜTAD } \\
\text { Çukurova Üniversitesi } \\
\text { Türkoloji Araştırmaları Dergisi }\end{array}$ & $\begin{array}{c}\text { Cilt 6, Sayı 1 } \\
\text { Haziran 2021 }\end{array}$ \\
\hline ISSN: 2587-1900 & $\begin{array}{c}\text { Geliş Tarihi: } \\
\text { E-ISSN: } 2548-0979\end{array}$ \\
\hline
\end{tabular}

Makale Künyesi (Araştırma): Karadağ Toprak, F. (2021). Tuva atasözlerinde geçen akrabalık adları üzerine bir inceleme. Çukurova Üniversitesi Türkoloji Araştırmaları Dergisi, 6 (1), 125-145.

https://doi.org/10.32321/cutad.820930

\title{
TUVA ATASÖZLERİNDE GEÇEN AKRABALIK ADLARI ÜZERINE BİR İNCELEME
}

\section{ÖZET}

\section{Fatoș KARADAĞ TOPRAK ${ }^{1}$}

Atasözleri; toplumun bilgeliğini, deneyimlerini, dünya görüşünü yansıtan, kuşaktan kuşağa aktarılan yüzyıllarca yaşayabilen sözlerdir. Ait olduğu toplumun söz varlığı hakkında çok fazla veri barındırmaktadır. Akrabalık adları ise insanı merkeze alan temel söz varlığının önemli bir parçasıdır. Akrabalık kan yoluyla ya da evlilik yoluyla oluşan bağa verilen addır. Akrabalık adlarının kullanımı, azlığı çokluğu, toplumun kültürel yapısının dile yansımasıdır. Tuvalar da zengin kültüre sahip ve bunu atasözlerine yansıtmış bir topluluktur. Bu çalışmada Tuvaların atasözlerindeki akrabalık adları incelenecek, atasözlerinde akrabalık adlarının ne şekilde ve ne sıklıkla kullanıldığı ortaya konulacaktır. Akrabalık adlarının atasözlerinde kullanımı tespit edilen örneklerle desteklenecektir.

Anahtar kelimeler: Tuvaca, Tuva atasözleri, akrabalık adları.

\section{A STUDY ON KINDSHIP NAMES IN TUVAN PROVERBS}

\begin{abstract}
Proverbs; are the words that reflect the wisdom, experiences and world view of the society and can live for centuries passed down from generation to generation. It contains a lot of data about the lexicon of the society to which it belongs. Kinship names are an important part of the basic lexicon that puts people in the center. Kinship is the name given to the bond formed by blood or marriage. The use of kinship names, the less and less, is the reflection of the cultural structure of the society on the language. Tuvans is a community with a rich culture and reflected this in proverbs. In this study, kinship names in proverbs of Tuvans will be examined, and how and how often kinship names are used in proverbs will be revealed. The use of kinship names in proverbs will be supported with examples identified.
\end{abstract}

Keywords: Tuvan, Tuvan proverbs, kinship names.

1 Çukurova Üniversitesi, Fen- Edebiyat Fakültesi, Türk Dili ve Edebiyatı Bölümü, Arş. Gör. karadagfatos@hotmail.com https://orcid.org/ 0000-0002-5019-3432 


\begin{tabular}{cr} 
ÇÜTAD & Tuva Atasözlerinde Geçen Akrabalık Adları \\
Haziran 2021 & Üzerine Bir İnceleme \\
\hline
\end{tabular}

\section{GíRIŞ}

Söz varlığının çekirdek yapısını temel söz varlığı oluşturmaktadır. Temel söz varlığının sınırları çizilirken insan merkeze alınır. İnsanın en yakınında bulunan en doğal gereksinimleri olan yeme, içme organları, en yakın kişileri gösteren akrabalık adları, sayı adları temel söz varlığı içerisinde yer almaktadır (Aksan, 2015, s. 34). Kişinin en yakın çevresinde aile ilişkileri ile ortaya çıkan; mensup olduğu milletin dünyaya bakış açısını, aile ve akrabalara verilen önemle şekil alan terim grubu akrabalık adlarıdır (Erdem, 2000, s. 187).

Akrabalık adları söz varlığının en arkaik katmanlarından biri olarak kabul edilmektedir. Bütün dillerde söz varlığının belirli bir bölümünü aile ve akrabalık isimleri oluşturmaktadır. İnsanlar günlük konuşma dilinde çok sayıda akrabalık terimi kullanırlar (Yazıcı Ersoy, 2001, s. 87). Tüm dillerin akrabalık terminolojisine sahip olması sebebiyle bu bileşen evrensel kabul edilir ancak toplumdan topluma farklılık göstermektedir (Taşbaş, 2019, s. 72). Toplumun kültürü, yerleşim tarzı, sosyal yapısı gibi sosyolojik unsurlar doğrudan dile yansımakta ve söz varlığında yaşamaktadır. Bu çalışmanın da odak noktasını oluşturan akrabalık adları çeşitli açılardan pek çok araştırmacı tarafindan da incelenmiştir².

2 Grønbech, K. (1953). The Turkish system of kindship. Studia Orientalia Johanni Peterson. Copenhagen: 124-129; Talat T. (1960) “' ‘amca' ve 'teyze’ kelimeleri hakkında”. Türk Dili Araştırmaları Yıllığı Belleten, 283-294; Pokrovskaya, L. A. (1961). "Terminı Rodstva v Tyurkskix Yazıkax", İstoriçeskoye Razvitiye Leksiki Tyurkskix yazıkov, (Red. E. İ. Ubryatova), 1181; Dankoff R. (1972). Kashgari on the tribal and kindship organization of the Trucs. Archivum Ottomanicum 4, 23-44. Caferoğlu, A. (1972) Kaşgarlı Mahmut'a göre akraba adları. Türk Dili Dil ve Edebiyat Dergisi, Ekim, C: XXVII, 253, 22-26; Gülensoy T. (1974) Altay Dillerindeki akrabalık adları üzerine notlar, Türk Dili Araştırmaları Yıllığ1-Belleten 283-318; Baştuğ, (1993). Kök Türük kindship terminology: an omaha model. Central Asiatic Journal 37/1 1-19; Sŏng Y. L. (1999). Türk dillerinde akrabalık adları, Simurg, İstanbul; Erdem, M. (2000). Türkmen Türkçesinde akrabalık terimleri üzerine. KÖK Araştırmalar Kök Sosyal ve Stratejik Araştırmalar Dergisi. II (1), 187-202; Gömeç, S. (2001). Köktürkçe belgelerdeki bazı akrabalık İsimleri. Türk Dünyası Tarih Dergisi, 173, 1-6; Gömeç, S. (2002). Divanu Lügat-it- Türk’de akrabalık bildiren kelimeler, Türk Kültürü, 39/464, 133-142; Biçe-ool, S. M. (2001). Tuvalılarda akrabalık sistemi", Bilig-17, Bahar, 107-116; Boikova, E. and Rybakov, R. B. (2006). Kinship in the Altaic world, Proceedings of the 48th PIAC.; Güner Dilek F. (2008). Altay Türklerinde akrabalık, Prof. Dr. Ahmet B. Ercilasun Armağan1, 541-563. Ergene, O. (2008). Türkiye Türkçesinde akrabalık terimleri ve söz varlığındaki kullanımları, Uluslararası Türk Dili Kurultayı Bildirileri, 1583-16404. Yazıcı Ersoy H. (2011). Başkurt Türkçesinde aile ve akrabalık isimlerinde kullanılan -y biçimbirimi. Türkbilig, 2011(21), 87- 
Akrabalık terimlerini anlamlandırabilmek için akrabalık sistemlerini anlayabilmek önemlidir. Akrabalık sistemleri 19. yy'ın sonunda ilk kez L. H. Morgan (1871) tarafından incelenmiştir. Akrabalık sistemleri Murdock (1949) tarafindan Hawai, Eskimo, Sudan, Iroquis, Omaha, Crow terminolojileri şeklinde altı başlıkta değerlendirilir (Taşbaş, 2020, s. 8). Sharon Baştuğ (1993), Köktürk Yazıtlarının akrabalık terminolojisini incelediği çalışmasında akrabalık terminolojik sisteminin, büyük olasılıkla antropologların Omaha dedikleri, ayrıntılı bir sistem olduğunu gösterdiğini belirtmektedir (s. 2). Omaha, babasoylu kökenli toplumlarda bulunan bir sinıflandırma sistemidir. Sistemin babasoylu karakteri, tanımlayıcı kategorilerde babasoylu sözcüklerin varlığı baskınken anne soylu terimler görece daha azdır (1993, s. 2). Bu sinıflamayı yapmak yalnızca kelime düzeyinde karşılaştırma değil sistematik olarak da benzerlik ve farklılıkları ortaya koymayı amaçlamaktadır.

Taşbaş (2019) ise çok geniş bir coğrafyaya yayılmış olan Türk dilinin belirli bir akrabalık sisteminin içine dâhil edilemeyeceğini ve yaşam biçimi, dil- kültür ilişkileri, bölgesel farklılıklar gibi sebeplerle heterojen bir görünümün ortaya çıktığını belirtmektedir (s. 8).

Türk dilinin akrabalık sistemini inceleyen ilk araştırmacılardan olan Grønbech (1953) aile yapısını yatay ve mutlak olarak değil, dikey ve göreceli olarak tanımlayarak adlandırmanın kronolojik olması gerektiğini yani belirleyici etmenin doğum sırası, tarihi olduğunu ifade etmektedir (s. 127). Türk dilinin akrabalık sistemini inceleyen son araştırmacılardan Taşbaş (2019) ise Türk dillerinin akrabalık terminolojisini çatallanma (iki kola ayrılma) yani anne tarafi, baba tarafi; teminat, miras yani aile bağı; nesil yani doğum tarihi; yaş ve cinsiyet başlıkları altında değerlendirmektedir (s. 246-250).

Güney Sibirya'da yaşayan Tuvaların akrabalık sistemi ise çeşitlilik gösteren bir yapıdadır. Tuvalar akrabalık bağlarına son

112; Emiroğlu, S. (2012). Türkçe sözlükteki akrabalık adlarının tasnifi. Turkish Studies - International Periodical For The Languages, Literature and History of Turkish or Turkic Volume, 7(4), 1691-1710, Yavuz, S. (2013). Türkiye Türkçesi ağızlarında akrabalık adları. Fırat Üniversitesi Sosyal Bilimler Dergisi, 23(2), 71-91; Hirik, E. (2017). Türkiye Türkçesi atasözlerinde akrabalık bildiren kelimeler ve duygu değerleri. İnsan ve Toplum Bilimleri Araştırmaları Dergisi, 6(3), 1726-1746. Taşbaş, E. (2019). The Turkic kindship system. Acta Orientalia Acadamiae Scientiarum Hung. 72(2), 245-258. Carlson, F. C. and Taşbaş, E. (2019). A typology of Turkic and Finno-Ugric kinship terms. Altay Toplulukları Aile ve Aile Değerleri, 105-112.

Taşbaş E. (2020). Türk dillerinde 'kuzen' terminolojisi. Hacettepe Üniversitesi, Türkiyat Araştırmaları Dergisi, 32, 7-22. 
derece önem vermektedirler. Tuvalılar akrabalarını derinlemesine bilir, Eski Tuva'da kendisini tanıtırken babasının ve mensubu olduğu oymağının adı ile tanıtırmış (Kenin- Lopsan, akt. Tosun, 2019, s. 104). Biçe-Ool (2001) Tuvalarda baba tarafından akrabalığın beşinci göbeğe kadar anne tarafindan akrabalığın dördüncü göbeğe kadar uzandığını ve doğrudan kan bağının ise dördüncü ve beşinci göbeğe kadar indiğini belirtmektedir. Ayrıca yakın akrabaların çöök törel genel olarak törel bölük olarak, yakın akrabalık dışında olanların trak törel uzak akrabalar olarak isimlendirildiğini han törel ve baar törel gruplarından oluşan yakın akraba grubu içinden evlenmenin Tuvalarda mümkün olmadığını da eklemektedir (s. 109). Tuvalarda bu evlenme yasağının günümüzde üç kuşağa kadar indiği bilinmektedir.

$\mathrm{Bu}$ çalışmada akrabalık adlarının kullanılışına dair incelenecek kaynak ise atasözleridir. Atasözleri toplumun ortak duyuşunu, düşünüşünü yansıtan kalıplaşmış sözlerdir. Toplumların karakteristik özelliklerinin bir anlamda söz varlığına yansımasıdır. Toplumun bilgeliğini deneyimlerini, dünya görüşünü yansitan yüzyıllarca yaşayabilen sözlerdir (Aksan, 2015, s. 41). Hem atasözleri hem de akrabalık adları söz varlığının önemli unsurları olup sosyolojik yapının dile yansıması konusunda ortaklık oluşturmaktadırlar.

Tuvalar diğer topluluklar gibi sözlü kültür geleneği içerisinde atasözlerini kuşaktan kuşağa aktarmışlardır. Tuvalar atasözüne üleger domak ve üleger sös demektedirler (Ölmez, 2009, s. 53). Ayrıca bazı çalışmalarda çeçen sös ifadesi de kullanılmaktadır (Aça, 2013, s. 32). Ölmez, çeçen sös ifadesinde yer alan çeçen sözcüğünün Moğolca "akıllı, zeki" anlamında Tuvacada da "zarif, şık konuşan" anlamında olduğunu belirtmektedir (2007, s. 113). Sözlüklerde ise çeçen sözü için "açık, belagatlı" anlamı verilmiştir Böylelikle Tuva atasözleri "belagatlı, zarif söz” anlamına gelmektedirler (Aça, 2013, s. 32). Tuva atasözleri şekil bakımından genellikle iki dizeden oluşmaktadırlar. Atasözlerinde dizeler genellikle 4-5, 5-6, 6-7,-8, 8-9, 9-10, 11-12 heceden oluşmaktadır. Dize sayısı üç ve dört olan atasözleri de bulunmaktadır (Aça, 2013, s. 40). Bu farklılığın da görülmesi açısından çalışmada atasözlerinin Kiril harfli biçimi şekil yapısına sadık kalınarak verilmiştir.

\section{YÖNTEM VE ÖRNEKLEM}

Çalışma kapsamında örneklem için seçilen metin B. K. Büdüp'ün Tıva Üleger Domaktar Bolgaş Çeçen Söster adlı çalışmasıdır. Büdüp'ün çalışması iki bölümden oluşmaktadır. İlk bölümde daha önceki kaynaklardan taranan atasözleri alfabetik olarak verilmiştir. İkinci bölümde ise yine Büdüp tarafindan derlenen daha önceki kaynaklarda yer almayan atasözleri yine alfabetik olarak sıralanmıştır. 
Eserin ilk bölümünde 514, ikinci bölümünde ise 256 atasözü bulunmaktadır. Ayrıca atasözlerinin Rusça açıklamaları da eserde yer almaktadır. Bu çalışmada takip edilen yöntem eserde geçen atasözleri Türkiye Türkçesine aktarılarak akrabalık adlarına dair unsurların tespit edilmesi şeklindedir.

\section{ATASÖZLERINDE GEÇEN AKRABALIK ADLARININ İNCELENMESI}

Kan yoluyla ya da evlilik yoluyla kurulan bağ olan akraba kavramı Tuvacada törel, dörgül- törel, elege, elege-esege ve haduүma sözcükleri ile karşılanmaktadır (Tosun, 2019, s. 104).

$\mathrm{Bu}$ kavramların içinde törel sözcüğünün ön plana çıtı̆ğ1 görülmektedir. Moğolcada törül sözcüğü "doğum, yeniden dünyaya gelme, hısım akraba" anlamlarına gelmektedir. Sözcük Güney Sibirya Türk dillerinde akraba kavramını karşılamakta, Tuvacada da törel biçimiyle kullanılmaktadır ( $\mathrm{Li}, 2019$, s. 58). Ve bu kelime bazı atasözlerinde kullanılmaktadır.

- Аът багын мунуп билир,

Төрел багын кирип билир (s. 13/54).

A't bagın munup bilir,/ Törel bagın kirip bilir.

“Atın kötüsünü binen bilir, akrabanın durumunu giden bilir."

- $\quad$ Төрел багы - аал чуду,

Төл багы — өг чуду (s. 44/306).

Törel bag1 - aal çudu, / Töl bag1 — ög çudu.

"Akrabanın kötüsü köyün ayıbı çocuğun kötüsü ailenin ayıbıdır."

\subsection{Kan Yoluyla Akrabalık Bildiren Sözcükler}

\section{Anne ile ilgili Sözcükler}

Tüm Türk dillerinde olduğu gibi kutsal bir değer atfedilen anne ile ilgili sözler Tuva atasözlerinde de sık kullanıma sahiptir. Tuvacada anne kavramını karşılamak için ava ve iye sözcükleri kullanılmaktadır. Fakat bir kişi annesine seslenirken ava sözcüğünü kullanmaktadır. Iye daha genel bir kullanım içindir.

\section{Ava (Ава) “Anne”}

Dîvânu Lugâti't-Türk'te yer alan apa "anne" sözcügü Türk dillerinde "anne" ya da "nine" anlamında kullanılmaktadır. Tuvacada da ava biçimiyle "anne" anlamında varlığını sürdürmektedir. Bu kapsamda tespit edilen atasözleri şu şekildedir: 
- Авага ажы-төлү артык,

Аңчыга алды-киш артык (s. 7/3).

Avaga ajı-tölü artık, /Añçıga aldı-kiş artık.

"Anneye çocukları kiymetli avcıya samur klymetlidir."

- Ава кижи “төлүм” дээр,

Ажы-төлү “шөлүм” дээр (s. 7/4).

Ava kiji "tölüm" deer, /Aj1-tölü "şölüm" deer.

"Anne evlatlartm der, evlatlar tarlam der."3

- Булут аразындан хүн караа чылыг,

Улус аразындан ава караа чымчак (s. 18/92).

Bulut arazından hün karaa çılıg, / Ulus arazından ava karaa çımçak.

"Bulutların arasında güneş ışınları daha sıcaktır, insanların arasında ise annenin gözleri daha yumuşaktır."

- Адазынга кызы чассыг,

Авазынга анай чассыг (s. 7/5).

Adazınga kızı çassıg, / Avazınga anay çassıg.

"Babasına klzı nazll, annesine oğlak nazlı."

- $\quad$ Ада чокта- чартык өскүс

Ава чокта- бүдүн өскүс (s. 8/13).

Ada çokta- çartık ösküs/ Ava çokta- büdün ösküs

“Baban yoksa yarı öksüz annen yoksa bütünüyle öksüzsün.”

- Авазы хүн болза,

Ачазы ай болур (s. 70/7).

Avazı hün bolza, /Açazı ay bolur.

"Anne güneş olsa, baba ay olur."

\section{İye (Иe ) “Anne”}

Ana ene sözcügü ilk olarak Eski Uygur Türkçesinde kullanılmış sonrasında yerini ög sözcügüne bırakmıştır (Li, 2019, s. 150). Çağdaş Türk dillerinde "anne, babaanne, kayınvalide" gibi anlamlarla varlığını sürdürmektedir. Tuvacada ise iye biçimiyle "anne" anlamında yaşamakta ve kullanımına atasözlerinde ava sözcüğünden daha fazla rastlanmaktadır. Bunu da genel bir kullanım olması ile ilişkilendirmek mümkündür. Sözcüğün tespit edildiği atasözleri şunlardır:

- Ада көрбээнин оглу көөр,

Ие көрбээнин уруу көөр (s. 7/7).

\footnotetext{
${ }^{3}$ Bu atasözü daha esnek bir çeviriyle "annenin gönlü çocuğunda çocuğun gönlü tarlada" şeklinde de anlamlandırılabilir.
} 


\begin{tabular}{cr} 
ÇÜTAD & Tuva Atasözlerinde Geçen Akrabalı Adları \\
Haziran 2021 & Üzerine Bir İnceleme \\
\hline
\end{tabular}

Ada körbeenin oglu köör,/ İye körbeenin uruu köör.

"Babanın görmediğini (yaşayamadığını) oğlu görür, annenin görmediğini (yaşayamadı̆̆ını) kızı görür."

- Иелиг кыс шевер,

Адалыг оол томаанныг (s. 23/136).

İyelig kıs şever, /Adalıg ool tomaannıg.

"Annesi olan klz hünerli, babası olan oğul hürmetkârdır."

- $\quad$ Тоткан эник ээзин ээрер

Доруккан оол иезин чаңчаар (s. 44/304).

Totkan enik eezin eerer, /Dorukkan ool iyezin çañçaar.

"Karnı doyan enik sahibine havlar, büyüyen oğul annesine kızar."

- $\quad$ Улус аразындан

Ие караа чымчак (s. 45/318).

Ulus arazından /İye karaa çımçak.

"Kalabalık arasında annenin gözleri yumuşaktır."

- Адазын дөзеер,

Ийезин уктаар. (s. 71/12).

Adazın dözeer, /Iyezin uktaar.

"Insan babaya benzer, anneden öğrenir."

- $\quad$ Адаң адаан адың

Иең адаан шолаң (s. 72/17).

Adañ adaan adıñ /İyeñ adaan şolañ

"Babanın verdiği adındır, annenin verdiği lakabındır."

- Ада сөзүн ажырып болбас,

Ие сөзүн ижип болбас (s. 8/10).

Ada sözün ajırıp bolbas/ İye sözün ijip bolbas.

"Baba sözünü unutma, anne sözüne hürmetsizlik etme”

- Ада сөзү — “амыдырал”,

Ие сөзу — “ажыл-иш” (s.72/21).

“Ada sözü -amıdıral / İye sözü -aj1l-iş .

"Baba sözü hayattır, anne sözü iştir"

- $\quad$ Ада төөгүзү — алдын,

Ие төөгүзү — мөңгүн (s. 72/23).

Ada töögüzü — aldın, /İye töögüzü - möñgün.

"Babanın mirası altındır, annenin mirası gümüştür."

- Иезин “инээм" дээр,

Адазын “аъдым" дээр (s. 90/160).

İyezin "ineem" deer, /Adazın "adım" deer.

"Annesine ineğim der, babasina atım der." 


\section{Baba ile ilgili Sözcükler}

Atasözlerinin öğüt verici nitelikte olması neticesinde; babanın insan hayatındaki yeri, babaya gösterilmesi gereken saygı gibi sebeplerden ve toplumlarda bir babaya bir köke sahip olmanın insanın varlığını tamamladığı düşünüldüğünden baba kavramını karşılayan sözcükler atasözlerinde sık karşılaşılan akrabalık adlarındandır. Bu sözler sözcüğü "baba" anlamının yanı sıra "ata, dede kök" gibi anlamları da karşılamaktadır. Tuvacada aadja, aça, açay, ada sözcükleri "baba" anlamında kullanılmaktadır. Ancak yapılan taramada atasözlerinde çoğunlukla ada sözcügüne ve $a c ̧ a$ sözcüğünün sadece bir kullanımına dair örneklere rastlanmıştır.

\section{Ada (Ада) "Ваba"}

Ata sözcüğünün kullanımına ilk defa Eski Uygur Türkçesi döneminde rastlanmış sonrasında yerini kay sözcügüne bırakmıştır (Li, 2019, s. 139). Bu sözcük günümüz Tük dillerine "baba” ve "dede” anlamlarıyla kullanılmaktadır. Tuvacada da ada biçimiyle "baba" anlamıyla varlığını sürdürmektedir. Atasözlerinde akrabalığa dair en çok kullanılan atasözlerindendir. Bu bağlamda tespit edilen atasözleri şunlardır:

- Адазынга кызы чассыг,

Авазынга анай чассыг (s. 7/5).

Adazınga kızı çassıg,/ Avazınga anay çassıg.

"Babasina kızı nazll, annesine oğlak nazlı."

- Ада кижи оглун сактыр,

Алдын-доос кудуруун сактыр (s. 7/6).

Ada kiji oglun saktır, /Aldın-doos kuduruun saktır.

"Baba oğlunu özler, tavus kuşu kuyruğunu özler."

- Адалыг оол томаанныг (s. 8/9).

Adalig ool tomaannig.

"Babası olanin sakin bir mizacı vardır".

- $\quad$ Адалыг кижи чоргаaр (s. 7/8)

Adalıg kiji çorgaar.

"Babası olan kişi gururludur."

- Ада сөзүн ажырып болбас,

Ие сөзүн ижип болбас (s. 8/10).

Ada sözün ajırıp bolbas/ iye sözün ijip bolbas.

"Baba sözünü önemsiz görme, anne sözüne hürmetsizlik etme”

- Ада чокта- эш чок,

Аъды чокта бут чок дег (s. 8/12).

Ada çokta- eş çok,/ A'dı çokta but çok deg. 
"Baba yoksa arkadaşın yok atın yoksa ayağın yok gibidir."

- $\quad$ Ада турда чон таныыр

Аът турда чер көөр (s. 8/11).

Ada turda çon tanır /A't turda çer köör.

"Babası varsa insanlarla tanışır, atı varsa yer görür."

- $\quad$ Ада чокта- чартык өскүс

Ава чокта- бүдүн өскүс (s. 8/13).

Ada çokta- çartık ösküs /Ava çokta- büdün ösküs

“Baban yoksa yarı öksüz annen yoksa bütünüyle öksüzsün.”

- Аът өлүр - баглаажы артар,

Ада өлүр - оглу артар (s. 13/57).

A't ölür — baglaajı artar,/ Ada ölür - oglu artar.

“At ölür bağlandı̆̆ kazık kalır, baba ölür oğlu kalır."

- $\quad$ тараалыг кижи тодуг

адалыг кижи чоргаap. (s. 43/300).

Taraalıg kiji todug/ adalıg kiji çorgaar.

"Ekmeği olan kişi tok, babası olan kişi gururludur."

- Адазын дөзеер,

Ийезин уктаар. (s. 71/12).

Adazın dözeer, /Iyezin uktaar.

“Insan babaya benzer, anneden öğrenir."

- $\quad$ Адаң адаан адың

Иең адаан шолаң (s. 72/17).

Adañ adaan adıñ /İyeñ adaan şolañ

"Babanın verdiği isim, annenin verdiği lakaptır."

- Ада орнун оол салгаар,

Аът орнун кулун салгаар. (s. 72/18).

Ada ornun ool salgaar, /A't ornun kulun salgaar.

"Babanın yeri oğluna, atın yeri tayına kalır."

- Ада сөзү - “амыдырал”,

Ие сөзү — “ажыл-иш” (s. 72/21).

Ada sözü — "amıdıral”, /İye sözü — "ajıl-iş".

“Baba sözü hayattır, anne sözü iştir”

- Ада сөзү - дашка баскан

таңма ышкаш (s. 72/22).

Ada sözü — daşka baskan /tañma 1şkaş.

"Baba sözü taşa basılan damga gibidir."

- $\quad$ Ада төөгүзү - алдын,

Ие төөгүзү — мөңгүн (s. 72/23).

Ada töögüzü — aldın, / İye töögüzü — möñgün. 
"Babanın mirası altındır, annenin mirası gümüştür."

- Иезин “инээм” дээр,

Адазын “аъдым" дээр (s. 90/160).

İyezin "ineem" deer, /Adazın "adım" deer.

"Annesine ineğim der, babasina atım der."

\section{Аça (Ача) "Ваba”}

Tuvacada baba anlamında kullanılan aça sözcügünün "ağabey, baba, büyükbaba" gibi anlamları da mevcuttur. Köken bakımından ise Eski Türkçedeki *aç- kökü ile ilişkilendirilebilir. Eski Türkçedeki $a c l$ fiili "birine üzülmek, vesayet etmek, merhamet vermek, hayırseverlik yapmak” gibi anlamlara sahiptir. Aça yani baba da bakım, vesayet, himaye vb. gösteren veya başka bir deyişle, kıdemli bir akrabayı karakterize eden eylemleri yapan kişidir. Buradan hareketle sözcük bu kök ile ilişkilendirilebilir (Tatarintsev, 2000, s. 156). Aça sözcüğü yalnızca bir atasözünde tespit edilmiştir.

- Авазы хүн болза,

$$
\text { Ачазы ай болур (s. 70/7). }
$$

Avazı hün bolza, /Açazı ay bolur.

“Annesi güneş olsa, babası ay olur.”

\section{Çocuklar İle İlgili Kullanılan Sözcükler}

Akrabalık adları içinde kullanımına en çok rastlanan sözcüklerden bir diğeri de çocuklara dair sözlerdir. Çocuklar için kls "kız" ve ool "oğul" sözcükleri kullanılmaktadır. Bir de daha genel bir adlandırma için töl "yavru, evlat”, ajl- töl "evlat”, urug "çocuk”, üren "evlat” sözcükleri kullanılmaktadır. Urug sözcüğünün "evlat "anlamında kullanımını bağlam belirlemektedir. Bu sözcük aslında genel anlamda çocuk kavramını karşılamak için kullanılmaktadır.

\section{Evlat İle İlgili Genel Sözcükler}

\section{Töl (төл) “Evlat”}

Töl sözcüğü temelde "torun, soy" anlamına sahip iken daha sonraları anlam genişlemesine uğrayarak "çocuk, doğmamış çocuk" anlamlarında kullanılmıştır. İlk defa Eski Uygur Türkçesi döneminde "soy, döl” anlamında kullanılmıştır (Clauson, 1972, s. 490). Tuva Türkçesinde de töl "evlat" anlamıyla üç atasözünde tespit edilmiştir.

- Кижи төлүнге ынак, 
Ыт коданынга ынак (s. 27/176).

Kiji tölünge ınak, /It kodanınga inak.

"İnsan yavrusunu sever, köpek sürüsünü sever."

- Арга-ыяш аразындан шиви чараш,

Арат чон аразындан төлү чараш. (s. 76/52).

Arga-ıyaş arazından şivi çaraş, /Arat çon arazından tölü çaraş.

"Dă̆ ormanı ăgaçları arasından köknar güzel, halk arasından çocuğu güzel."

- Кижиниң байы төлүнде. (s. 96/208)

Kijiniñ bayı tölünde.

"Kişinin zenginliği çocuklarıdır."

\section{Urug (Уруг) “Çocuk”}

Urug sözcüğü esas olarak "tohum, çekirdek, tane" anlamına sahip iken mecazi olarak "soy, nesil" gibi anlamlara sahiptir. Orhon Türkçesinde "soyunu kurutmak" anlamında urugssırat- eylemi bulunmaktadır (Li,2019, s. 64). Tuvacayı söz varlığı açısında tesiri altına alan Moğolcada da "akraba" anlamında urug sözcügü de yaşamaktadır (Lessing, 885b). Tuvacada ise urug sözcüğü genel olarak çocuk anlamında kullanılmaktadır. "Bir insanın çocuğu" anlamında ise tespit edilen bir atasözü örneği bulunmaktadır.

- Уялыг куш чаныган,

Уруглуг кижи кээргээчел. (s. 46/325).

Uyalıg kuş çanıgan, / Uruglug kiji keergeeçel.

"Kuş yuvasını korur, çocuklu kişi yavrusuna merhamet eder."

\section{Kız Evlat İle İlgili Sözcükler}

Atasözlerinde daha çok anne ile özdeş görülerek, anne tarafindan biçimlenen bir karaktere sahip olduğuna vurgu yapılan kız çocuğu için Tuva atasözlerinde kullanılan akrabalık adları incelendiğinde sadece $k \imath s$ sözcüğü tespit edilmiştir.

\section{Kıs (Кыс )“Kız çocuk”}

Kız sözcüğünü temelde “ kız, evlenmemiş kadın” anlamına sahip iken "kız evlat, cariye gibi anlamlarda da kullanılmıştır (Clauson, 1972, s. 679). İlk kez Orhon Yazıtlarında "kız evlat" anlamıla kullanıldığı görülmektedir. Tuvacada da kls biçimiyle "kız evlat" anlamında kullanılmaktadır. $\mathrm{Bu}$ bağlamda tespit edilen atasözleri şunlardır:

- Даш кагган черинге чыдар, 
Кыс берген черинге олурар (s. 20/116).

Daş kaggan çeringe çıdar, /Kıs bergen çeringe olurar.

"Taş attığın yerde kalır, kız verdiğin yerde yaşar."

- Кыс берген черинге олурар. (s. 32/211).

Kıs bergen çeringe olurar.

“Kız verildiği yerde yaşar."

- $\quad$ Кыс уруг ине-чүскүк дээр, (s. 32/212)

Оол уруг оттук-бижек дээр.

Kıs urug ine- çüskük deer, /Ool urug ottuk-bijek deer.

"Kız çocuk iğne yüksük ister, oğlan çocuk çakmak ile bıçak ister".

- Кыс этке ынак,

Оол аътка ынак (s. 32/212).

Kıs etke inak, /Ool a'tka inak.

“Kız çocuğu varlı̆̆a eşyayı sever, oğlan çocuğu atı sever”.

- Кыштаг турда, мал белен,

Кыстыг турда, күдээ белен. (s. 32/214).

Kıştag turda mal belen/ K1stı1g turda küdee belen.

"Kışlak olduğunda mal hazır, kızlı olduğunda damat hazır."

- Оолдуг кижи оя сөглээр,

Кыстыг кижи кыя сөглээр. (s. 35/236).

Oolug kiji oya sögleer/Kıstıg kiji kıya sögleer.

"Oğlu olan kişi doğrudan söyler, kızı olan kişi nazla söyler."

- Кижиниң оглу оол-биле дөмей,

Кижиниң кызы кыс-биле дөмей (s. 96/211).

Kijiniñ oglu ool-bile dömey, /Kijiniñ kızı kıs-bile dömey.

"İnsanın oğlu, erkek yaşıtlarına benzer, İnsanın kızı, kız yaşıtlarına benzer."

\section{Erkek Evlat İle İlgili Sözcükler}

Atasözlerinde kıymeti daha çok babası üzerinden şekillenen bir konumda olan erkek evlat için Tuva atasözlerinde ool sözcügünün kullanılan tek akrabalık adı olduğu tespit edilmiştir.

\section{Оol (Оол) “Erkek Çоcuk”}

Og்ll sözcüğü Orhon Yazıtlarında "kız ya da erkek evlat" anlamında kullanılmaya başlanmış aynı durum Eski Uygurcada da devam etmiştir ( $\mathrm{Li}, 2019$, s. 258). Tuvacada da "erkek evlat" anlamıyla kullanılmaktadır. Tuvacada iki ünlü arasında kalan /g/ sesinin büzüşmesiyle oluşan ikincil uzunluklar neticesinde sözcük ool biçimini almıştır (Koçoğlu Gündoğdu, 2018, s. 66). Ool sözcüğü iyelik eki aldığında oglum biçimine dönüşmektedir. Ogul sözcüğü 
akrabalık adlarının atasözlerinde sık olarak kullanıldığını gösteren örneklerdendir. Bu bağlamda ortaya çıkan atasözleri şunlardır:

- Аът өлүр - баглаажы артар,

Ада өлүр - оглу артар (s. 13/57).

A't ölür — baglaajı artar,/ Ada ölür - oglu artar.

“At ölür bağlandı̆̆ kazık kalır, baba ölür oğlu kalır."

- Кыс уруг ине-чүскүк дээр,

Оол уруг оттук-бижек дээр. (s. 32/212)

Kıs urug ine- çüskük deer, /Ool urug ottuk-bijek deer.

"Kız çocuk iğne yüksük ister, oğlan çocuk çakmak ile bıçak ister".

- К Кыс этке ынак,

Оол аътка ынак (s. 32/212).

Kis etke inak, /Ool a'tka inak.

"Kız çocuğu varlı̆̆a eşyayı sever, oğlan çocuğu atı sever."

- Оолдуг кижи оя сөглээр,

Кыстыг кижи кыя сөглээр. (s. 35/236).

Oolug kiji oya sögleer /Kıstıg kiji kıya sögleer.

"Oğlu olan kişi doğrudan söyler, kızı olan kişi nazla söyler."

- Тоткан эник ээзин ээрер,

Доруккан оол иезин чаңчаар (s. 44/304).

Totkan enik eezin eerer, /Dorukkan ool iyezin çañçaar.

"Karnı doyan enik sahibine havlar, büyüyen oğul annesine kızar."

- Кижиниң оглу оол-биле дөмей,

Кижиниң кызы кыс-биле дөмей (s. 96/211).

Kijiniñ oglu ool-bile dömey, /Kijiniñ kızı kıs-bile dömey.

"Oğlan çocuğu, erkek yaşıtlarına benzer, kız çocuğu, kız yaşıtlarına benzer."

- Ада орнун оол салгаар,

Аът орнун кулун салгаар. (s. 72/18).

Ada ornun ool salgaar, /A't ornun kulun salgaar.

"Babanın yeri oğluna, atın yeri tayına kalır."

\section{Kardeşler İle İlgili Sözcükler}

\section{Duџma (Дуңма) “Küçük kız ya da erkek kardeş”}

Genellikle Güney Sibirya'da konuşulan Türk dillerinde rastlanan tuүma sözcüğü kesin olmamakla birlikte tug่- köküne dayandırılabilir. Sözcügün Türk dillerinde "küçük kız kardeş, erkek kardeş, yeğen, kuzen" gibi anlamlarla kullanıldığı görülmektedir (Li, 2019, s. 212). Tuvacada duyma biçimiyle kullanılan sözcük "erkek kardeş" ya da 
"kız kardeş" anlamında kullanılmaktadır. Yapılan taramada yalnızca iki atasözünde tespit edilmiştir.

- Кижиниң дуңмазы карааның огу, баарының өдү болур (s. 96/209).

Kijiniñ duñmazı karaanıñ ogu, /baarınıñ ödü bolur.

"İnsanın kardeşi gözünün bebeği, ciğerinin parçası olur."

- Дунмалыг кижи дыш,

Угбалыг кижи ус (s. 22/129).

Duñmalıg kiji dış, /ugbalıg kiji us.

"Küçük kardeşi olan sakin, ablası olan hünerlidir."

\section{Ugba (Угба) “Abla"}

Ugba sözcüğünü dayandırdığımız $u b a$ sözcüğü büyük olasılıkla Yenisey Samoyedcesinin "kız kardeş" anlamına gelen sözcüğünden gelmektedir (Li, 2019, s. 189). Günümüz Türk dillerinin ikisinde "abla ve hala" anlamlarında yaşamaktadır. Bu diller Tuvaca ve Tofacadır. $\mathrm{Bu}$ çalışma kapsamında yapılan taramada sözcüğün yalnızca "abla" anlamında kullanıldığı iki örneğine rastlanmıştır.

- Дуңмалыг кижи дыш,

Угбалыг кижи ус (s. 22/129).

Duñmalıg kiji dış, /ugbalıg kiji us.

"Küçük kardeşi olan sakin, ablası hünerlidir."

- Угбалыг кижи ус (s. 45/312).

Ugbalıg kiji us.

"Ablası olan kişi ustadır, hünerlidir."

\section{Dayı, Amca, Hala ve Teyze İle Sözcükler}

Atasözlerinde dayı, amca, hala, teyze gibi daha uzak akrabalık adlarının kullanımının az olduğu, hatta neredeyse hiç kullanılmadığı görülmektedir. Tuvacada "amca" anlamında akl/akly, "dayı" anlamında daay, "teyze" anlamında daay-ava, "hala" anlamında ugba ya da ugbay sözcükleri kullanılmaktadır. Tekin (1988), teyze sözcügünü açılarken *tay-ezesi ya da *tayl-ezesi biçiminde açıklamakta ve "dayının ablası" gibi bir anlam vermektedir (s. 294). Aynı şekilde Tuvacada da daay "dayı" ve ava "anne" sözcüklerinin birleşimiyle benzer şekilde oluşmuştur. Bu sözcüklerin anlam sınırları keskin çizgilerle belirlenmemiştir. Bazen birbirlerinin yerine kullanıldıkları da görülmektedir. Bu çalışmada yalnızca daay "dayı" sözcügünü örnekleyen bir atasözü tespit edilmiştir Daay "dayı" sözcüğü araştırmacılarca genellikle tagay sözcügüne dayandırılsa da Sertkaya (2008), bu sözcügü Çinçe tay “büyük"sözcüğüne eklenen $+y$ 
küçültme ekinin üzerine gelen iyelik eki neticesinde oluştuğunu belirtmektedir (s. 156). Benzer durum Tuvacada da mevcuttur. Sonunda $+y$ bulunduran ve akrabalık ilişkisini ifade eden sözler küçültme şekillerinden oluşmuş ve kullanıldığı sözcüğe avay "anneciğim" örneğinde olduğu sevgi anlamı katmaktadırlar (Palmbah \& İshakov, 2019, s. 152.).

\section{Daаy (Даай) “Day”"}

Daay sözcüğüne kaynaklık eden tag்ay sözcüğü Eski Türkçede tay ata, tay ene gibi birleşikler oluşturmuş ve ilk olarak Uygur Türkçesinde tespit edilmiştir ( $\mathrm{Li}, 2019$, s. 169). Sözcük yalnızca aşağıdaki atasözünde tespit edilmiştir.

- Даг көргенде, бөрү омак,

Даай көргенде, чээн омак (s. 19/103).

Dag körgende, börü omak, /Daay körgende, çeen omak.

"Dağı görünce kurt sevinir, dayısını görünce yeğen sevinir."

\section{Yeğen, Kuzen İle İlgili Sözcükler}

Atasözlerinde az rastlanılan akrabalık adlarından bir diğeri de yeğen, kuzen gibi sözcüklerdir. Tuva atasözlerinde bu bağlamda yalnızca bir atasözü kullanımı tespit edilmiştir.

\section{Çeen (чээн ) "Yeğen"}

Yegen sözcüğü Eski Türkçede asıl olarak "küçük kız kardeşin oğlu, erkek torun" gibi anlamlarla kullanılmış ve ilk olarak Uygurcada tespit edilmiştir (Li, 2019, s. 276). Tuvacada iki ünlü arasında kalan /g/ sesinin büzüşmesiyle ve söz başı /y-/ sesinin /c-/ sesine dönüşmesiyle ceen biçimini almıştır. Tespit edildiği yalnızca bir atasözü şu şekildedir:

- Даг көргенде, бөрү омак,

Даай көргенде, чээн омак (s. 19/103).

Dag körgende, börü omak, /Daay körgende, çeen omak.

"Dağı görünce kurt sevinir, dayısını görünce yeğen sevinir."

\subsection{Evlilik Yoluyla Akrabalık Bildiren Sözcükler}

\section{Eşler İle İlgili Sözcükler}

Evlilik yoluyla oluşan akrabalık adlarının temelinde karı koca için kullanılan sözcükler yer almaktadır. Fakat bu adların atasözlerinde nadiren kullanıldıkları tespit edilmiştir. Tuvacada aşak "koca" kaday "hanım, kadın”, kattaş “eş, hanım”, aşaktıg "evli kadın”, kadaylıg 
“evli erkek" sözcükleri eşler için kullanılan akrabalık adlarındandır. Çalışmada yalnızca kaday sözcüğünü örnekleyen atasözlerine rastlanmıştır. Ayrıca eş için kijinin kijisi şeklinde bir örnekle de karşılaşılmıştır.

- Кижиниң малы саарында таңмалыг, кулаанда имниг.

Кижиниң кижизи салаазында билзектиг, кулаанда сыргалыг (s. 96/210).

Kijiniñ malı saarında tañmalıg, / kulaanda imnig. / Kijiniñ kijizi salaazında bilzektig, kulaanda sirgalıg.

"İnsanın malının üzeri damgalı, kulağ i işaretli; insanın karısının parmă̆ yüzüklü, kulağı küpelidir."

\section{Kaday (кадай ) "Eş, Hanım, Kadın”}

Kaday sözcüğünü kada "yaşlı kadın" köküne dayandırmak mümkündür. Katanov şüpheli de olsa kada sözcüğünün Samoyedçe olabileceğini düşünmektedir. Kada sözcüğünün modern Tuva sözlüklerinde bulunmaması dolayısıyla da kaday sözcüğü ile ilişkisi kurulamamıştır. Ayrıca Moğolcada da gadam/hadam "karı koca" için kullanılmaktadır (Tatarintsev, 2004, s. 36). Kaday sözcüğüne dair Tuva atasözlerinde yalnızca iki örnek tespit edilmiştir.

- $\quad$ Харам кадай - өг чуду (s. 49/342).

Haram kaday - ög çudu

"Cimri eş ailenin ayıbıdır."

- Калбак кезек -от чуду,

Харам кадай -өг чуду (s. 25/152).

Kalbak kezek -ot çudu, Haram kaday -ög çudu.

"Düz kütük ateșin ayıbl, cimri hanım evin ayıbı."

\section{Gelin ve Damat İle İlgili Kullanılan Sözcükler}

Atasözlerinde gelin ve damada ilişkin söz varlığının sayıca çok olmadığı, tespit edilen atasözlerinden damat ile ilgili olanların daha fazla olduğu görülmektedir. Tuvacada "gelin" kelin, kenetter, "damat" için küdee sözcügü kullanılmaktadır.

\section{Küdee / Күдээ "Damat"}

Küdee sözcügü Eski Türkçede küdegü "güvey” sözcüğüne dayanmaktadır. *Küde- "evlenmek" fiiline fiilden isim yapan -gü yapım ekinin eklenmesiyle oluşmuştur. (Doerfer, 1971, s. 298). Ayrıca sözcüğün etimolojisinin belirsiz olduğuna ya da *küy- / *küd-, 
olabileceği konusunda da görüşler bulunmaktadır (Tatarintsev, 2004, s. 336). Yapılan taramalarda sözcüğe aşağıdaki atasözlerinde rastlanmıştır.

- Кыштаг турда, мал белен,

Кыстыг турда, күдээ белен. (s. 32/214).

Kıştag turda mal belen /Kıstıg turda küdee belen.

"Kışlak olduğunda mal hazır, kız olduğunda damat hazır."

- Хүн херелдиг,

Күдээ дузалыг (s. 53/377).

Hün hereldig /Küdee duzalıg.

"Güneş ışık verir, damat fayda verir."

- $\quad$ Хүрең-дайның маңын көөр,

Күдээзиниң күжүн көөр (s. 53/378).

Hüreñ-daynıñ mañın köör, / küdeeziniñ küjün köör.

"Kahverengi tayının hızını gör, damadının gücünü gör."

\section{Kelin /келин “Gelin”}

Kelin sözcüğü kel- "gelmek" fiilinden türemiş bir isimdir. Gelinin aileye gelen kişi olmasından hareketle bu adlandırma yapılmıştır. İlk kez Orhon Türkçesinde kullanımına rastlanmıştır (Li, 2019, s. 420). Tuvacada da hiçbir değişikliğe uğramadan kelin biçimiyle aynı anlamda varlığını sürdürmektedir. Bir atasözünde kelin sözcüğü örneklenmiştir.

- Кежиглиг хемни үер үрээр,

Кежээ келинии хоп үрээр (s. 26/163).

Kejiglig hemni üer üreer, /Kejee kelinii hop üreer.

"Geçilebilecek nehirleri sel bozar, çalışkan gelinleri dedikodu bozar."

\section{Kayınvalide ve Kayınpeder İle İlgili Sözcükler}

\section{Katı (Каты) “Kayınpeder”}

Tuvacada katı ve kat sözcükleri "kayınpeder" ve "kayınbirader" anlamlarına gelmektedir. Ayrıca Batı Moğolistan Tuvalarında, kataja ve kat-ada sözcüklerinin de kayınbirader anlamında kullanıldığı kaydedilmiştir (Tatarintsev, 2004, s. 126). Kat1 sözcüğünün etimolojisi $k a t \imath<k a t t \imath<* k a d n \imath<k a d ı n+\imath<(k a d ı n<* k a \bar{d} ı n)$ şeklinde açıklanabilir (Li, 2019, s. 79). Tuva atasözlerinde bir adet atasözünde katı sözcüğü tespit edilmiştir.

- Катының ергинин артап,

Кат-ийезин арнын көрүп 
таныжар (s. 94/190).

Katınıñ erginin artap, /Kat-iyezin arnın körüp /tanıjar

"Kayınpederin eşiğini geçen kayınvalidenin yüzünü görüp tanışır."

\section{Kat- İyezi ( Кат-ийези) "Kayınvalide”}

Tuvacada kat-iyezi sözcüğü "kayınvalide" ya da "büyük baldız" anlamlarında kullanılmaktadır (Tatarintsev, 2004, s. 126). Sözcüğü *kadın-iye "gelinin annesi" biçimine dayandırmak mümkündür $(\mathrm{Li}$, 2019, s. 79). Katı sözcüğü ile birlikte aynı atasözünde yer almaktadır.

- К Катының ергинин артап,

Кат-ийезин арнын көрүп

таныжар (s. 94/190).

Katınıñ erginin artap, /Kat-iyezin arnın körüp /tanıjar

"Kayınpederin eşiğini geçen kayınvalidenin yüzünü görüp tanışır."

\section{Yenge İle İlgili Sözcükler}

Tuva atasözlerinde evlilik yoluyla kurulan akrabalık adlarından bir diğeri yenge kavramını karşılayan sözlerdir. Tuvacada "yenge" için çenge ve çaa ava biçiminden gelişen çaava sözcükleri kullanılmaktadır. Çenge sözü için bir atasözü tespit edilmiştir. Ancak çaava sözcüğü tespit edilememiştir.

\section{Çenge /(Чеңге ) "Yenge"}

Yenge sözcüğü "babanın küçük erkek kardeşinin karısı" ve "ağabeyin karısı" anlamıyla Eski Türkçede bulunmaktadır. İlk olarak Uygur Türkçesi metinlerinde geçmektedir (Li, 2019, s. 364). Eski Türkçedeki söz başı $/ y$-/ sesinin /ç-/ sesine dönüşmesiyle çenge biçiminde Tuvacada yaşayan sözcük bir atasözünde tespit edilmiştir.

- Чеңнээш чокта, хол соок,

Чеңге чокта, чем соок. (s. 57/417).

Çeñneeş çokta, hol sook, /Çeñge çokta, çem sook.

"Eldiven yoksa eller soğuk, yenge yoksa yemek soğuk."

\section{SONUÇ}

Atasözleri toplumun geçmişten geleceğe inanışlarını, geleneklerini, kültürlerini taşıdıkları kalıplaşmış sözlerdir. Bu çalışma kapsamında incelenen Tuva atasözlerinde akrabalık adlarına dair şunlar tespit edilmiştir.

İnsanın yakın çevresinden uzağa akrabalık adlarının kullanımı ve sıklığı azalmaktadır. Bu durumun temel söz varlığının insanı merkeze 
almasıyla ilişkili olduğunu söylemek mümkündür. $\mathrm{Bu}$ sebeple atasözlerinde en çok kullanılan sözcük "baba" anlamına gelen ada olmuştur. Elbette sözcügün temel anlamının yanı sıra "ata, kök" gibi anlamları da bu sonuca etki etmiştir. Bu durum da babasoylu kökenli toplumlarda bulunan bir sinıflandırma sistemi olan Omaha'nın etkilerindendir. Biçe Ool (2001) "Tuvalıların akrabalık sistemi eski düal akrabalık bağlı egzogami normlardan, kuvvetli bir baba tarafından akrabalık ve baba tarafına odaklı sisteme doğru evrim geçirdi” demektedir (s. 114). Aslında baba odaklı akrabalık sistemi ve baba odaklı sosyolojik yapının atasözlerinin kelime varlığına yansıması görülmektedir.

Baba sözcüğünden sonra en fazla bulunan sözler anneye dair olan iye ve ava sözcükleridir. $\mathrm{Bu}$ da Tuvalıların anaerkil dönemine ait kalıntıların göstergelerindendir.

Tuva akrabalık sisteminde yaş önemli bir unsurdur. Duฑma “küçük kız ya da erkek kardeş” ve ugba “abla” sözcükleri de bu duruma tanık niteliğindedir.

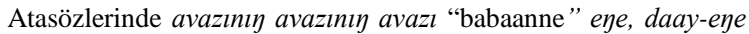
“anneanne” ve ögbe ,adazını adazı “dede” sözcükleri tespit edilememiştir. $\mathrm{Bu}$ durum bu sözlerin daha çok çocuk merkeze alındığında kullanılan, daha çok çocuk dilinde kullanılan akrabalık adları olması ile ilişkili olabilir. Ada "baba" ve iye "anne" adları ise çocuk diline ait adlar olmasına rağmen kavram alanı geniş sözcüklerdir.

Kan yoluyla kurulan akrabalık adlarının evlilik yoluyla kurulan akrabalık adlarından daha fazla olduğu tespit edilmiştir. Evlilik yoluyla kurulan akrabalık adlarına dair 9 atasözü, kan yoluyla kurulan akrabalık adlarına dair ise 59 atasözü tespit edilmiştir.

Çalışmada toplam 770 atasözü incelenmiştir. 52 farklı atasözünde akrabalık adları tespit edilmiştir. Aynı atasözünde genellikle birden fazla akrabalık adının varlığı tespit edilmiştir.

\section{KAYNAKÇA}

Aça, M. (2011). Tıva atasözleri. Karadeniz Araştırmaları Dergisi, 3(12), 29-50.

Aksan, D. (2000). En eski Türkçenin izlerinde. İstanbul: Simurg Yayınları.

Aksan, D. (2007). Her yönüyle dil ana çizgileriyle dilbilim. Ankara: Türk Dil Kurumu Yayınları. 


$\begin{array}{cr}\begin{array}{c}\text { ÇÜTAD } \\ \text { Haziran 2021 }\end{array} & \text { Tuva Atasözlerinde Geçen Akrabalık Adları } \\ \text { Üzerine Bir İnceleme }\end{array}$

Aksan, D. (2015). Türkçenin sözvarlı̆ğ. Ankara: Bilgi Yayınevi.

Arıkoğlu, E. (2007). Tuva Türkleri atasözleri. Türk Dünyası Edebiyat Metinleri Antolojisi, 8, 257-262.

Arıkoğlu, E. ve Kuular, K. (2003). Tuva Türkçesi sözlüğü. Ankara: Türk Dil Kurumu Yayınları.

Baştuğ, S. (1993). Kök Türük kindship terminology: an omaha model. Central Asiatic Journal, 37(1), 1-19.

Biçe-ool, S. M. (2001). Tuvalılarda akrabalık sistemi. Bilig 17, 107116.

Büdüp, B. K. (2010). Tlva üleger domaktar bolgaş çeçen söster. Kızıl: Tivanı̇ Yu. Ş. Kyunzegeş Attıg Nom Ündürer Çeri.

Erdem, M. (2000). Türkmen Türkçesinde akrabalık terimleri üzerine. KÖK Araştırmalar, II(1), 187-202.

Grønbech, K. (1953).The Turkish system of kindship. Studia Orientalia Johanni Peterson. Copenhagen, 124-129.

İshakov, F. G, ve A. A. Palmbah (2019). Tuva dili grameri ses ve şekil bilgisi. Bengü Yayınları, Ankara.

Kenin- Lopsan, M. (2019). Tuvaların gelenekleri (İlker Tosun, Akt.). Ankara: Bengü Yayınları.

Koçoğlu Gündoğdu, V. (2018). Tuva Türkçesi grameri. Ankara: Türk Dil Kurumu Yayınları.

Li, S.Y. (2019). Türk dillerinde akrabalık adları. Ankara: Türk Dil Kurumu Yayınları.

Ölmez, M. (2007). Tuwinischer wortschatz mit alttürkischen und mongolischen parallelen. Wiesbaden: Harrasowitz Verlag.

Ölmez, M. (2009). Tuva atasözlerinden seçmeler. Sibirya Incelemeleri, 4(1), 51-128.

Sertkaya, O. F. (1983). Çince tay "büyük" kelimesi ile yapılan damla, dayı, teyze ve dede kelimeleri üzerine. Türk Dili, XCVI, 680, 150159.

Taşbaş E. (2019). The Turkic kindship system. Acta Orientalia Acadamiae Scientiarum Hung. 72(2), 245-258.

Taşbaş E. (2020). Türk dillerinde 'kuzen' terminolojisi. Hacettepe Üniversitesi, Türkiyat Araştırmaları Dergisi, 32, 7-22. 


$\begin{array}{cr}\begin{array}{c}\text { ÇÜTAD } \\ \text { Haziran 2021 }\end{array} & \text { Tuva Atasözlerinde Geçen Akrabalık Adları } \\ \text { Üzerine Bir İnceleme }\end{array}$

Tatarintsev, B. İ. (2000). Etimologiçeskiy slovar' Tuvinskogo yazıka tom I. Novosbirsk. Nauka.

Tatarintsev, B. İ. (2004). Etimologiçeskiy slovar' Tuvinskogo yazıka tom IV. Novosbirsk. Nauka.

Tekin, T. (1988). Amca ve teyze kelimeleri hakkında. Türk Dili Araştırmaları Yıllığı Belleten, 283-294.

Tosun, İ. (2019). Cinsiyet kategorisi bağlamında Tuva Türkçesinin söz varlığı. Türk Bitig Türklük Bilimi Araştırmaları, 99-122.

Yazıcı Ersoy, H. (2011). Başkurt Türkçesinde aile ve akrabalık isimlerinde kullanılan -y biçimbirimi. Türkbilig, 2011(21), 87112. 